\title{
A survey relation of organizational culture and organizational citizenship behavior with employees' empowerment
}

\author{
Seyyed Ebrahim Sadati *
}

M.Sc in the Public Administration, Tarbiat Modares University, Tehran, Iran

\begin{tabular}{|c|c|}
\hline ART ICLE I N F O & ABSTRACT \\
\hline $\begin{array}{l}\text { Article history: } \\
\text { Received March 8, } 2012 \\
\text { Received in Revised form } \\
\text { April, 18, } 2012 \\
\text { Accepted 25 May } 2012 \\
\text { Available online } \\
\text { May 31 } 2012 \\
\text { Keywords: } \\
\text { Organizational culture } \\
\text { Organizational citizenship } \\
\text { behavior } \\
\text { Employees' empowerment }\end{array}$ & $\begin{array}{l}\text { The aim of this study is to study the relationship between organizational culture and } \\
\text { organizational citizenship behavior (OCB) with employees' empowerment. Empowering } \\
\text { employee's breeds success by providing a suitable framework to utilize the necessary skills in } \\
\text { an attempt to realize organizational goals. In this paper, four dimensions of employees' } \\
\text { empowerment including meaningfulness, choice, competence and impact are investigated. We } \\
\text { also identify four dimensions for organizational culture including adaptability, consistency, } \\
\text { involvement and mission. The paper also specifies five basic dimensions of OCB, which } \\
\text { consists of altruism, conscientiousness, sportsmanship, courtesy and civic virtue. These basic } \\
\text { dimensions of both independent and dependent variables construct the research conceptual } \\
\text { model and the required data is gathered from the Tehran Municipality. This proposed study } \\
\text { considers } 180 \text { employees who participated in our survey. The investigation of the proposed } \\
\text { model is also performed based on the Structural Equation Modeling (SEM). }\end{array}$ \\
\hline
\end{tabular}

(C) 2012 Growing Science Ltd. All rights reserved.

\section{Introduction}

Nowadays, many researchers participate in the field of empowering employees and in this area of research, valuable results have been presented for organizations and firms across the world. Empowerment is a concept, philosophy, or set of organizational and behavioral practices where a company vests decision-making or approval authority to employees (Pinchot, 2000). Empowerment is a set of policies allowing self-managing teams and individuals to be in charge of careers and destinies (Pinchot, 2000). Empowering employee's breeds success by providing the framework to the workforce to unleash, to develop, and to utilize skills to realize organizational goals (Helgesen, 2000). This study aims to investigate the relationship between organizational culture and organizational citizenship behavior (OCB) with employees' empowerment. In any work environment, it is possible to find individuals who contribute beyond specified job requirements. These are the people who exhibit certain helpful behaviors. Such desirable discretionary contributions are called as

\footnotetext{
* Corresponding author. Tel: +98-9121053853

E-mail addresses: seyyedebrahimsadati@gmail.com (S.E. Sadati) 
organizational citizenship behaviors (Jackson, 2009). On the other hand, Organizational culture has been under special attention among managers and it has always been considered as one of the components of organizational effect. Content to the organizational culture of organizations is formed after an organization is influenced by other dimensions. Despite various studies in organizational culture, many organizations are still suffering as a cultural richness. There are perhaps strong organizational culture growths and prosperity of organizations is seeking.

Therefore, the following questions are investigated in this study,

1. What are the main effective dimensions of OCB in the statistical population of this study?

2. What are the main effective dimensions of organizational culture in the statistical population of this study?

3. What is the relationship between OCB and employees' empowerment in the statistical population of this study?

4. What is the relationship between organizational culture and employees' empowerment in the statistical population of this study?

5. What is the fit model for relationship between these three basic variables including OCB and organizational culture with the employees' empowerment?

\section{Literature review}

\subsection{Employees' empowerment}

Empowerment is a kind of a journey to a destination (Kaye \& Jordan-Evans, 2002) and today's business environment requires administrators to visualize the direction the organization very clearly (Baird, 2006). On a basic level employee empowerment is granting power to the stakeholders doing the work (Petter et al., 2002). Many empowerment programs are based on innovation, greater effectiveness, and better performance (Castello, 2002) but many people think more about it (Castello, 2002). It requires skill, dynamics, and communication techniques, which could be time consuming (Petter, et al., 2002). Empowerment programs, to be effective, need the full support of management throughout the process and empowerment needs to be an ongoing concern (Baird, 2006).

Empowerment is a concept, philosophy, or a set of organizational behavioral practices where a company vests decision-making or approval authority to employees (Pinchot, 2000). Empowerment is policies allowing self-managing teams and individuals to be in charge of careers and destinies (Pinchot, 2000). Empowering employee's breeds success by providing the framework to the workforce in order to utilize the necessary skills to reach organizational goals (Helgesen, 2000). These types of programs place the responsibility for decisions further within the organization (Petter et al., 2000). Empowerment is making all stakeholders responsible for daily tasks and the everyday jobs at hand (Messmer, 2004). Empowerment does not advocate giving up control, but rather changing the way control is implemented (Messmer, 2004). Giving employees greater responsibility is an effective application of an organizations vision to the development and utilization of the human resource asset (Baird, 2006). Empowerment changes the organizational culture in such a way that there would be no conflict between the objectives of firms and individuals (Petter, et al., 2000 cited in Baird, 2006).

Empowering stakeholders leads to better customer focus, quality, and continuous improvement (Petter, et al., 2000 cited in Baird, 2006). Empowerment is the necessary means and techniques in service to accomplish firms' requirements (Messmer, 2004) and it can be carefully measured by customer satisfaction (Messmer, 2004). Managers must believe that a change in culture can be made and that the individual leader is the force, which could make the change a reality (Helgesen, 2000 cited in Baird, 2006). Empowerment can increase motivation to remove mistakes and helps stakeholders take responsibility for actions on the job (Newstrom, 2004). Furthermore, empowerment increases the opportunity for innovation, creativity, and goal focus. The process assists with continuous improvement, customer satisfaction, and help management team reach cost saving 
decisions. The program assists employee to be more loyal and self-managing teams for employee control and productivity and it provides more responsibility for the employee, which ends to have a culture of pride, self-worth, and self-respect (Messmer, 2004).

In this study, the cognitive empowerment model of Thomas and Velthouse is used to construct the basic model of the research. There are four cognitions or task assessments as the basis for worker empowerment including sense of impact, competence, meaningfulness, and choice (Thomas \& Velthouse, 1989). They adopted an interpretive framework and used the resulted framework to describe cognitive processes. Widespread use of the empowering has come at a time when global competition and change have forced a search for alternative forms of management (Thomas \& Velthouse, 1989). A facilitative management style, which encourages commitment, risk-taking, and innovation must be used to enhance the new competitive forces in the external environment (Thomas \& Velthouse, 1989). This trend has been apparent in the fields of leadership and organizational culture where different investigation have indicated that leaders could energize workers (Thomas \& Velthouse, 1989).

Assessments in the models are an individual's generalized beliefs about:
- Meaningfulness
- Choice
- Competence
- Impact

The above four basic elements are the core for current study's model. These assessments are more conceptual beliefs compared with specific task assessments, which motivates an employee's behavior (Thomas \& Velthouse, 1989). According to Rotter (1966) the notion of locus of control is formed over time by the individual's assessments based on the impact of the employee's performance on specific tasks. In turn, task assessments are shaped deductively in part by an individual's global assessments (Thomas \& Velthouse, 1989).

\subsection{Organizational citizenship behavior (OCB)}

In any work environment, it is possible to detect individuals who contribute beyond specified job requirements. These are the people who provide certain useful behaviors such as company resources. They normally admit reasonable inconvenience without any objection, provide good suggestions, and act in a manner consistent with god team players. Such desirable discretionary contributions are called as organizational citizenship behaviors (OCB) and it is described as "beneficial behavior of workers, which was not prescribed but occurred freely to help others achieve the task at hand" (Di Paola, 2005; Jackson, 2009). Katz (1964) is believed to be the first who introduced the term of OCB on extra role behaviors. Then Organ and Beetman (1983) introduced total concept of OCB and it is also called "the good soldier syndrome" (Organ, 1988).

Other terms for this concept are as follow: Contextual Performance, Organizational Spontaneity, Civic Organizational Behavior, Pro-social Organizational Behavior, etc. (Bragger \& et al., 2005; Padasakoff \& et al. 2000; Somech \& Zahavy 2004). OCB specifies those activities not considered as organizational qualifications, but the activities, which are useful for organizations. These behaviors might not be rewarded; therefore, employees are not rewarded for these pro-social behaviors. Nevertheless, these behaviors lead to rewarding later (Organ 1997). There are also cases where employee might be rewarded for OCB but awards are not always received and have non-linear relationship with behavior (Bragger et al., 2005). OCB, in essence, is assumed to be a cooperative behavior, which means people of the organization support each other (Barnard 1983; Van Dyne \& et al 1995). OCB develops effective performance of organization, elevates organization as a whole and recommends it to other parties (Williams \& Anderson, 1991). Structural viewpoint used concept of "organization" to define OCB. It is also believed that employee should have knowledge, ability and opportunity to do predicted and extra role behaviors (Ahmadi et al., 2010). Kwantez (2003) divides all determinants of OCB into two main groups of individual and organizational characteristics. The 
most important individual determinants include individual values, job attitude, individual commitment to organization, individual perception of job, organization and management support, perception of degree of justice in organizational exchanges and emotional states. The most important organizational determinants include culture, organizational structures, and practices of human resources and method of organizational exchanges (Ahmadi et al., 2010).

In this study, we use five-category model developed by Organ (1988) to construct the basic research model in this study. Organ (1988) introduced five distinct categories for OCB, which are altruism, conscientiousness, sportsmanship, courtesy, and civic virtue (Jackson, 2009). These basic five categories are described as follow:

- Altruism: altruism or helping behaviors consist of all behaviors in which an individual assists someone in completing organizationally related tasks. An example of altruism is someone helping a struggling co-worker complete his/her assigned paperwork or put away stock in the store room even through the helper received no tangible benefit from helping. Subcategories of cheerleading and peacekeeping were included within this dimension.

- Conscientiousness: This term is also called compliance and it is associated with individuals going well beyond the minimum expectations.

- Sportsmanship: This explains how workers address inconvenience and disruption. The unexpected occurs in every work setting, but the good sport handled these events with good nature and without compliant.

- Courtesy: courtesy means workers who communicated with their colleagues, provided advance notice of changes in their work schedule, or described to others about decisions, which could influence their jobs.

- Civic Virtue: This term describes actions associated with contributing the organizational governance. Attending meetings, making constructive recommendations concerning company rules and procedures, and agreeing to serve on or lead committees were typical civic virtue behaviors (Jackson, 2009).

Therefore, basic hypothesis to measure the relationship between OCB and Employees' Empowerment is as follow:

\section{H1: Organizational Citizenship Behavior (OCB) is positively related to Employees’ Empowerment.}

\subsection{Organizational culture}

Organizational culture as one of the components of organizational effect has always been under special consideration among managers and theorists. Numerous studies on organizational culture and its relationship with other components such as job satisfaction, performance, productivity and efficiency confirm this (Ebrahimpour et al., 2011). Content to the organizational culture of organizations formed after that the organization is influenced by other dimensions. Despite the fact that there are various studies in organizational culture, many organizations are suffering as a cultural richness (Ebrahimpour et al., 2011). Organizational culture refers to shared assumptions, values, and norms (Schein, 1985). Organizational culture is a source of sustained competitive advantage (Barney, 1991) and empirical research shows that it is a key factor to organizational effectiveness (Deal \& Kennedy, 1982; Denison, 1990; Gordon \& Di Tomaso, 1992; Ouchi \& Jaeger, 1978; Peters \& Waterman, 1982; Wilkins \& Ouchi, 1983). In particular, many people identified and validated four dimensions of organizational culture, which are conducive to organizational effectiveness (Denison, 1990; Denison and Mishra, 1995; Denison and Neale, 1996; Fey and Denison, 2003):

- Adaptability

- Consistency

- Involvement

Mission

Adaptability refers to the degree in which an organization maintains the ability to alter behavior, structures, and systems to survive in the wake of environmental changes. Consistency is associated 
with the extent in which beliefs, values, and expectations are held consistently by members. Involvement refers to the level of participation by an organization's members in decision making. Mission is the existence of a shared definition of the organization's purpose (Zheng et al., 2010). This study uses this framework.

H2: Organizational Culture is positively related to Employees' Empowerment.

\section{The research conceptual model}

Based on detailed literature review and determine the basic dimensions of both independents and dependent variables, in this section the conceptual model of research is presented. As is obvious from the conceptual model of research, basic dimensions of employees' empowerment are encompasses: Meaningfulness, Choice, Competence and Impact; also basic dimensions of organizational citizenship behavior are encompasses: Altruism, Conscientiousness, Sportsmanship, Courtesy and Civic Virtue; and finally organizational culture dimensions include: Adaptability, Consistency, Involvement and Mission. Fig. 1 shows the research conceptual model.

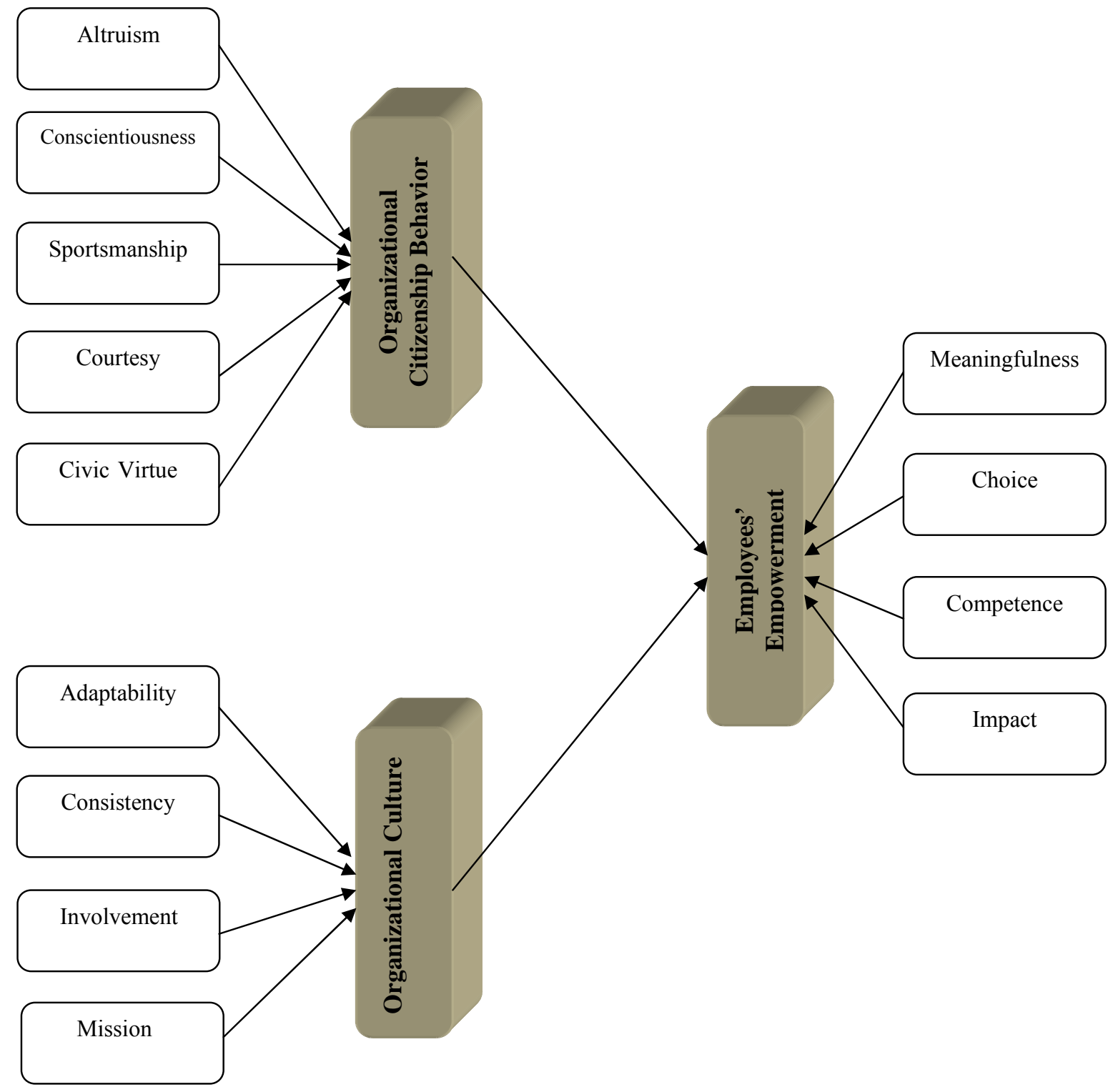

Fig. 1. The research conceptual model 


\section{Methodology}

The study consists of 180 employees of Tehran Municipality who participated in the survey. Table 1 shows details of their personal characteristics in terms of their educational level and their work experience.

Table 1

Statistical population and sample

\begin{tabular}{lcc}
\hline Characteristics & Numbers & Percent (\%) \\
\hline Educational level: & & 47 \\
BS and lower & 84 & 37 \\
MA & 68 & 16 \\
PhD & 28 & 23 \\
Work experience: & 42 & 36 \\
Less than 5 year & 65 & 26 \\
5 to 10 year & 47 & 15 \\
10 to 15 year & 26 & \\
15 year and more & & \\
\hline
\end{tabular}

\subsection{Data collection}

The basic tool for data gathering in this research was questionnaire. Also the most important methods of collecting data in this study are as below:

1) Documentary studies: document sources, articles, required books and internet was used in this part in order to collect information about theoretical base and research literature and also to identify the basic dimensions of each of the independent and dependent variables and constructing the research conceptual model.

2) Field Studies: in this part in order to collect data and information so that analyze and test the basic research model, questionnaires were used.

Also for data analysis the SPSS18.0 and LISREL8.7 software were used and according to software package basic and related statistical tests were defined and then were run.

\subsection{Validity and reliability}

Validity and reliability are two necessary features for every measuring material such as questionnaire because these materials should analyze data and provide final conclusions for researchers.

\subsubsection{Validity}

To sum up, validity means that a measuring material is used to measure the characteristics. In this research to confirm the validity of the research's questionnaire, Factor Analysis was used. For questionnaire of this research there were 28 questions (except 2 descriptive questions) and after factor analysis, common amounts of all items were above the 0.5 and remained in the analysis. Table 2 shows the KMO of Sampling Adequacy for this research, Sig and Bartlett's Test of Sphericity which all demonstrated that research is so appropriate and valid.

\section{Table 2}

Results of factor analysis test for validity of the research

\begin{tabular}{lc}
\hline Statistic of the Test & Items of questionnaire \\
\hline KMO of Sampling Adequacy & 0.805 \\
Bartlett's Test of Sphericity & 1033.668 \\
df & 287 \\
Sig & 0.000 \\
\hline
\end{tabular}




\subsubsection{Reliability}

To meet the reliability confirmation in this research, Cronbach's alpha was calculated. A questionnaire consists of 30 questions was used for data collection. Two questions were about descriptive statistics and characteristics of respondents and measured by numerical measures. Others were evaluated by the Likert 5-choice measurement. Cronbach's alpha Coefficient was used to measure reliability and it was calculated for 13 basic elements and categories of this research and it was 0.902 , which is well above the mean acceptable alpha and it means the questionnaire is reliable. Reliability of the questions was evaluated. Table 3 shows the results (Cronbach Alpha is used to test the reliability of the materials used in the research). All these parts bear high reliability $(a>0.7)$.

Table 3

Reliability test results

\begin{tabular}{|c|c|c|c|}
\hline \multicolumn{4}{|c|}{ Case Processing Summary } \\
\hline & & $\mathrm{N}$ & $\%$ \\
\hline \multirow{3}{*}{ Cases } & Valid & 179 & 99.4 \\
\hline & Excluded $^{\mathrm{a}}$ & 1 & .6 \\
\hline & Total & 180 & 100.0 \\
\hline \multicolumn{4}{|c|}{ Reliability Statistics } \\
\hline \multicolumn{3}{|c|}{ Cronbach's Alpha } & $\mathrm{N}$ of Items \\
\hline \multicolumn{3}{|c|}{0.902} & 16 \\
\hline
\end{tabular}

\section{Data analysis}

For measuring the model by using gathered data, t-test, Pearson Bi-variate Correlation test and also Structural Equation Modeling (SEM) have been used.

\subsection{Measuring the dimensions of $O C B$}

First, to determine the affectability of all dimensions of independent and dependent variables, one sample t-test has been used. Table 4 and Table 5 show the results of one sample t-test for OCB dimensions. Results illustrate that all 5 dimensions including: Altruism, Conscientiousness, Sportsmanship, Courtesy and Civic Virtue are positively affected on OCB.

\section{Table 4}

Results of One-Sample Statistics for OCB dimensions

\begin{tabular}{lcccc}
\hline OCB dimensions & $\mathrm{N}$ & Mean & Std. Deviation & Std. Error Mean \\
\hline Altruism & 180 & 3.5611 & 1.29961 & .09687 \\
Conscientiousness & 180 & 3.8778 & .92547 & .06898 \\
Sportsmanship & 180 & 3.7056 & .94955 & .07078 \\
Courtesy & 180 & 4.4389 & .81305 & .06060 \\
Civic Virtue & 180 & 3.8611 & .92007 & .06858 \\
\hline
\end{tabular}

Table 5

Results of One-Sample Test for OCB dimensions

\begin{tabular}{|c|c|c|c|c|c|c|}
\hline \multirow[t]{2}{*}{ OCB dimensions } & \multirow[t]{2}{*}{$\mathrm{t}$} & \multirow[t]{2}{*}{ df } & \multirow{2}{*}{$\begin{array}{c}\text { Sig. } \\
\text { (2-tailed) }\end{array}$} & \multirow{2}{*}{$\begin{array}{c}\text { Mean } \\
\text { Difference }\end{array}$} & \multicolumn{2}{|c|}{$\begin{array}{l}95 \% \text { Confidence Interval of } \\
\text { the Difference }\end{array}$} \\
\hline & & & & & Lower & Upper \\
\hline Altruism & 5.793 & 179 & .000 & .56111 & .3700 & .7523 \\
\hline Conscientiousness & 12.725 & 179 & .000 & .87778 & .7417 & 1.0139 \\
\hline Sportsmanship & 9.969 & 179 & .000 & .70556 & .5659 & .8452 \\
\hline Courtesy & 23.744 & 179 & .000 & 1.43889 & 1.3193 & 1.5585 \\
\hline Civic Virtue & 12.557 & 179 & .000 & .86111 & .7258 & .9964 \\
\hline
\end{tabular}




\subsection{Measuring the dimensions of Organizational Culture}

Table 6 and Table 7 show the results of one sample t-test for Organizational Culture dimensions. Results illustrate that all 4 dimensions including: Adaptability, Consistency, Involvement and Mission are positively affected on Organizational Culture.

\section{Table 6}

Results of One-Sample Statistics for Organizational Culture dimensions

\begin{tabular}{lcccc}
\hline Organizational Culture Dimensions & $\mathrm{N}$ & Mean & Std. Deviation & Std. Error Mean \\
\hline Adaptability & 180 & 3.9500 & 1.09481 & .08160 \\
Consistency & 180 & 3.9667 & 1.06178 & .07914 \\
Involvement & 179 & 3.8771 & 1.09467 & .08182 \\
Mission & 180 & 3.7000 & .99664 & .07429 \\
\hline
\end{tabular}

Table 7

Results of One-Sample Test for Organizational Culture dimensions

\begin{tabular}{lcccccc}
\hline $\begin{array}{c}\text { Organizational Culture } \\
\text { Dimensions }\end{array}$ & $\mathrm{t}$ & $\mathrm{df}$ & $\begin{array}{c}\text { Sig. } \\
\text { (2-tailed) }\end{array}$ & $\begin{array}{c}\text { Mean } \\
\text { Difference }\end{array}$ & \multicolumn{2}{c}{$\begin{array}{c}\text { 95\% Confidence } \\
\text { Interval of the } \\
\text { Difference }\end{array}$} \\
\hline Adaptability & 11.642 & 179 & .000 & .95000 & Lower & Upper \\
Consistency & 12.215 & 179 & .000 & .96667 & .7890 & 1.1110 \\
Involvement & 10.720 & 178 & .000 & .87705 & 1.1228 \\
Mission & 9.423 & 179 & .000 & .70000 & .5156 & 1.0386 \\
\hline
\end{tabular}

\subsection{Measuring the dimensions of Employees' Empowerment}

Table 8 and 9 show the results of one sample t-test for Employees' Empowerment dimensions. Results illustrate that all 4 dimensions including: Meaningfulness, Choice, Competence and Impact are positively affected on Employees' Empowerment.

Table 8

Results of One-Sample Statistics for Employees' Empowerment dimensions

\begin{tabular}{lcccc}
\hline \multicolumn{1}{c}{ Employees' Empowerment dimensions } & $\mathrm{N}$ & Mean & Std. Deviation & Std. Error Mean \\
\hline Meaningfulness & 180 & 3.5778 & 1.21423 & .09050 \\
\hline Choice & 180 & 3.4778 & 1.04884 & .07818 \\
\hline Competence & 180 & 4.3667 & .87740 & .06540 \\
\hline Impact & 180 & 4.1389 & 1.13730 & .08477 \\
\hline
\end{tabular}

\section{Table 9}

Results of One-Sample Test for Employees’ Empowerment dimensions

\begin{tabular}{ccccccc}
\hline $\begin{array}{c}\text { Employees' } \\
\text { Empowerment } \\
\text { dimensions }\end{array}$ & $\mathrm{t}$ & $\mathrm{df}$ & $\begin{array}{c}\text { Sig. } \\
\text { (2-tailed) }\end{array}$ & $\begin{array}{c}\text { Mean } \\
\text { Difference }\end{array}$ & \multicolumn{2}{c}{$\begin{array}{c}\text { 95\% Confidence } \\
\text { Interval of the } \\
\text { Difference }\end{array}$} \\
\cline { 6 - 8 } & & & & & Lower & Upper \\
\hline Meaningfulness & 6.384 & 179 & .000 & .57778 & .3992 & .7564 \\
Choice & 6.112 & 179 & .000 & .47778 & .3235 & .6320 \\
Competence & 20.898 & 179 & .000 & 1.36667 & 1.2376 & 1.4957 \\
Impact & 13.435 & 179 & .000 & 1.13889 & .9716 & 1.3062 \\
\hline
\end{tabular}




\subsection{Relationship between OCB and Employees’ Empowerment}

In order to measure the relationship between OCB and Employees' Empowerment in this study the Pearson Bi-variate Correlation test has been used. Result of this test is presented in the Table 10.

Table 10

Pearson correlation test results to measure the H1

\begin{tabular}{cccc}
\hline & Correlations & \\
\hline Basic variables & Test parameters & OCB & Empowerment \\
\hline \multirow{2}{*}{ OCB } & Pearson Correlation & 1 & $0.695^{* *}$ \\
& Sig. (2-tailed) & - & .000 \\
& $\mathrm{~N}$ & 180 & 180 \\
\hline \multirow{3}{*}{ Empowerment } & Pearson Correlation & $0.695^{* *}$ & 1 \\
& Sig. (2-tailed) & .000 & - \\
& $\mathrm{N}$ & 180 & 180 \\
\hline
\end{tabular}

**. Correlation is significant at the 0.01 level (2-tailed).

As obvious from the results of Table 10, there is a strong and positive relationship between OCB and Employees' Empowerment. The Pearson's coefficient for these two basic variables in the study is 0.695 (approximately 0.70 ) at the $99 \%$ confidence level.

\subsection{Relationship between Organizational Culture and Employees’ Empowerment}

In order to measure the relationship between Organizational Culture and Employees' Empowerment in this study the Pearson Bi-variate Correlation test has been used. Result of this test is presented in the Table 11.

\section{Table 11}

Pearson correlation test results to measure the $\mathrm{H} 2$

\begin{tabular}{cccc}
\hline Basic variables & Test parameters & OCB & Empowerment \\
\hline \multirow{2}{*}{ Organizational Culture } & Pearson Correlation & 1 & $.641^{* * *}$ \\
& Sig. (2-tailed) & - & .000 \\
& $\mathrm{~N}$ & 180 & 180 \\
\hline \multirow{2}{*}{ Empowerment } & Pearson Correlation & $.641^{* *}$ & 1 \\
& Sig. (2-tailed) & .000 & - \\
\hline **. Correlation is significant at the 0.01 level (2-tailed). & $\mathrm{N}$ & 180 & 180 \\
\hline
\end{tabular}

As obvious from the Table 10, there is a strong and positive relationship between Organizational Culture and Employees' Empowerment. The Pearson's coefficient for these two basic variables in the study is 0.641 at the $99 \%$ confidence level.

\subsection{Structural Equation Modeling (SEM)}

In order to run the basic conceptual model in the study the Structural Equation Modeling (SEM) has been used. Using LISREL8.7 this model has been runes. Results showed that the model of this study was highly appropriated to present the relationship between basic variables of the study and also between dimensions of basic independent and dependent variables. Fig. 2 shows the SEM results for the model of this research.

Also Table 12 shows the results of fitness the model of SEM for this research. As obvious from the table this model is completely fit to present the relationships between variables and dimension of the research's model. 


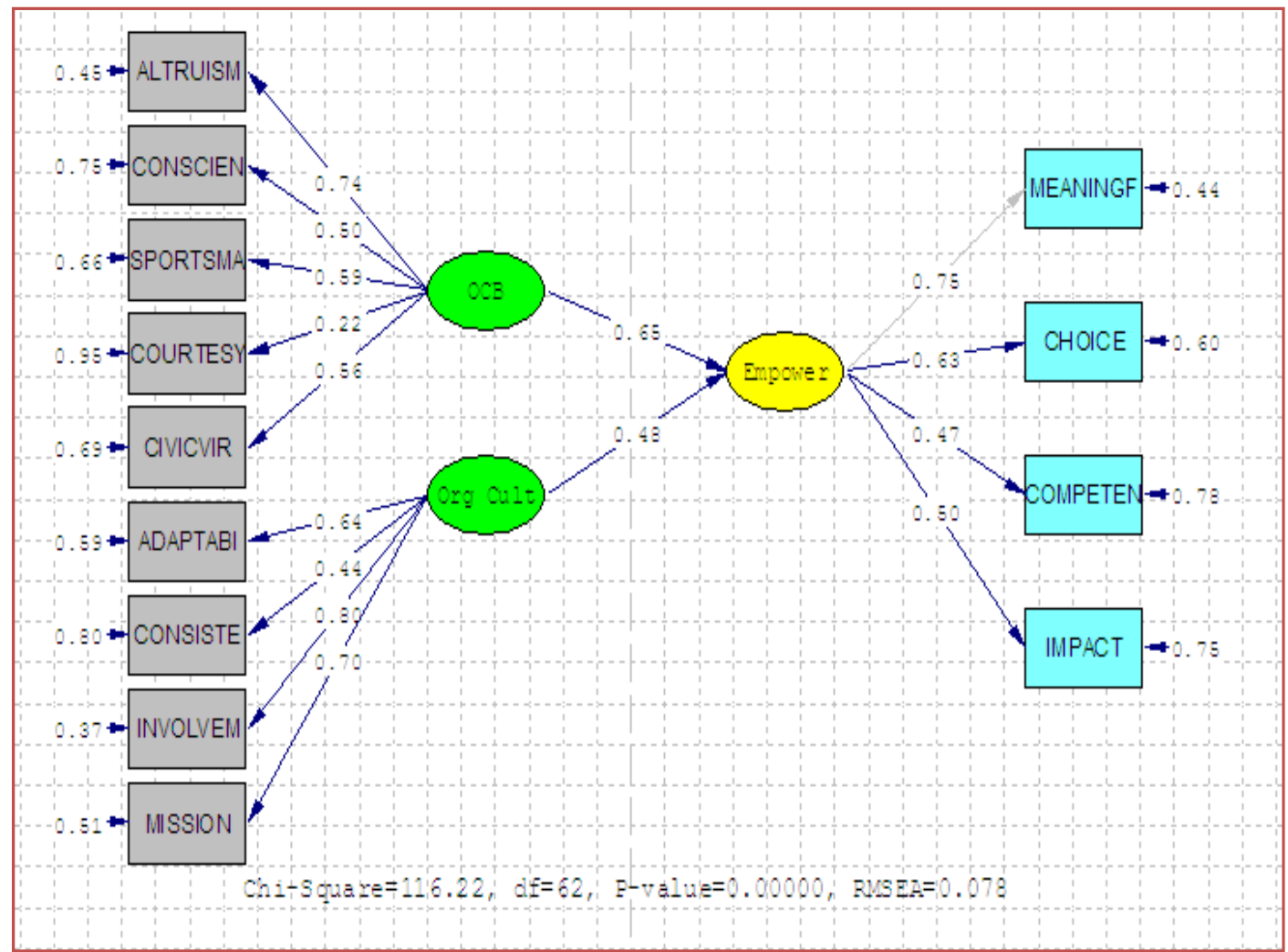

Fig. 2. Standardized Solutions of SEM for the conceptual model

As Fig. 3 shows, all of the elements of the SEM model according to the amount of t-value of the model have been remained in the model. In the other word, all of the elements of the model at the 95 percent of confidence level have participated and affected on the whole of the research model.



Fig. 3. T-Value amounts of SEM for the conceptual model 
Table 12

Indices of Fitness for Structural Model of research

\begin{tabular}{cccccccccc}
\hline Structural model & $\chi^{2}$ & $\mathrm{df}$ & $\mathrm{p}$ & $\chi^{2} / \mathrm{df}$ & RMSEA & CFI & GFI & AGFI & RMR \\
\hline Basic conceptual model & 116.22 & 62 & 0.000 & 1.87 & 0.078 & 0.92 & 0.80 & 0.75 & 0.085 \\
\hline
\end{tabular}

\section{Conclusion}

This survey study aimed to investigate the valid relationship between organizational citizenship behavior and organizational culture with employees' empowerment. For achieve this main purpose, after detailed review of literature and research background, four basic related dimensions of employees empowerment consisted of: meaningfulness, choice, competence and impact; four dimensions for organizational culture consisted of: adaptability, consistency, involvement and mission; and also five basic dimensions of OCB consisted of: altruism, conscientiousness, sportsmanship, courtesy and civic virtue have been identified. Based on these main dimensions and elements, basic conceptual model has been presented. This basic model clearly show the relationship between main independent and dependent variables including $\mathrm{OCB}$, organizational culture and employees' empowerment and also the relationship between dimensions of these independent and dependent variables. Based on data gathered from the statistical population, appropriate statistical tests have been applied. Finally, structural equation modeling (SEM) for constructing the basic relationships have been applied and presented. Results demonstrated that there were strong and positive relationships between OCB and employees' empowerment. This means that in the organization or departments of organization that have the real accomplished OCB, employees were enthusiastically endeavored to play an important role in the organization. When employees tend to do organizational activities willingly and enjoy for apply these works, they potentially best ready to empower with the organization.

Also results demonstrated that there were strong and positive relationships between organizational culture and employees' empowerment. This means organization that foster and supports the innovation, creativity and other valuable activities related to the efficiency and effectiveness of the organization, have positive impact to empower the employees. Constructive organizational culture will foster the employees' empowerment process and it provides a context to enhance organizational effectiveness. It is strongly recommended that managers build the supportive atmosphere in the every section of the organizations in order to achieve the empowering employees positively and simply.

\section{References}

Ahmadi, P., Forouzandeh, S., \& Safari Kahreh, M. (2010). the relationship between OCB and Social Exchange Constructs. European Journal of Economics, Finance and Administrative Sciences, 19, 107-120.

Baird, J. (2006). the intent to leave: an investigation of empowerment mechanisms, job satisfaction, and organizational commitment among technical college employees (Doctoral Dissertation). Retrieved from ProQuest Dissertations and Theses database.

Barnard, C. I. (1983). The Functions of the Executive, Cambridge. MA: Harvard University Press.

Barney, J. (1991). Firm resources and sustained competitive advantage. Journal of Management, 17 (1), 99-120.

Bragger, J., Rodriguez-Srednicki, O., Kutcher, E., Indovino, L., \& Rosner, E. (2005). Work-family conflict, work-family culture, and organizational citizenship behavior among teachers. Journal of Business and Psychology, 20, 303-324.

Deal., T.A., \& Kennedy, A.A. (1982). Corporate culture. Reading. MA: Addison-Wesley.

Denison, D.R., Mishra, A.K. (1995). toward a theory of organizational culture and effectiveness. Organization Science, 6 (2), 204-23.

Denison, D.R., \& Denison, N.W.S. (1996). Organizational culture survey. Ann Arbor: Aviat.

Denison, D.R. (1990). Corporate culture and organizational effectiveness. New York: Wiley. 
Ebrahimpour, H., Zahed, A., Khaleghkhah, A., \& Sepehri M. B. (2011). A survey relation between organizational culture and organizational citizenship behaviour. Procedia - Social and Behavioural Sciences, 30, $1920-1925$.

Fey, C.F., \& Denison, D.R. (2003). Organizational culture and effectiveness: can American theory be applied in Asia? Organization Science, 2003, 14(6), 686-706.

Gordon, G.G., \& Di Tomaso, N. (1992). Predicting corporate performance from organizational culture. Journal of Management Studies, (29), 783-98.

Jackson, J. C. (2009). Organizational citizenship behaviors, collective teacher efficiency, and student achievement in elementary schools (Doctoral Dissertation). Retrieved from ProQuest Dissertation and Theses database.

Katz, D. (1964). The motivational basis of organizational behavior. Behavioural Science, 9, 131146.

Kaye, B., \& Jordan-Evans, S. (2002). Love 'em or lose "em: Getting good people to stay (10thed.). San Francisco: Barrett-Koehler.

Organ, D. (1997). Organizational citizenship behavior: It's construct clean-up time. Human Performance, 10, 85-97.

Organ, D. W. (1990). The motivational basis of organizational citizenship behavior. Research in Organizational Behaviour, 12, 43-72.

Organ, D.W. (1988). Organizational citizenship behaviour: The good soldier syndrome. Lexington, MA: Lexington Books.

Organ, D.W., \& Konovsky, M. (1989). Cognitive versus affective determinants of organizational citizenship behavior. Journal of Applied Psychology, 74, 157-164.

Organ, D.W., \& Ryan, K. (1995). A meta-analytic review of attitudinal and dispositional predictors of organizational citizenship behavior. Employee Psychology, 48, 775-800.

Ouchi WG, \& Jaeger A. M. (1978). Type Z organization: stability in the midst of mobility. Academy of Management Review, 3(2), 305-314.

Peters T., \& Waterman R. (1982). In search of excellence. New York: Harper and Row.

Petter, J., Byrns, P., Choi, D., Fegan, F., \& Miller, R. (2002). Dimensions and pallet in empowerment: Assessing what matters to street-level bureaucrats. Journal of Public Administration Research and Theory, 12, 377-396.

Podsakoff, P.M., Mac Kenzie, S.B., Paine, J. B., \& Bachrach, D. G. (2000). Organizational citizenship behaviors: A critical review of the theoretical and empirical literature and suggestions for future research. Journal of Management, 26, 513-563.

Schein, E. H. (1985). Organizational culture and leadership: a dynamic view. San Francisco, CA: Jossey-Bass.

Somech, A., \& Drach-Zahavy, A. (2004). Exploring organizational citizenship behavior from an organizational perspective: The relationship between organizational learning and organizational citizenship behavior. Journal of Occupational and Organizational Psychology, 77, 281-229.

Thomas, K. W. \& Velthouse, B.A. (1989). Cognitive elements of empowerment: An interpretive model of intrinsic task motivation. Academy of Management Review, 15, 666-681.

Van Dyne, L., Cummings, L. L., \& Parks J. M. (1995). Extra-role behaviors: In pursuit of construct and definitional clarity: A bridge over muddied waters. Research in Organizational Behaviour. L. L. Cummings and B. M. Staw (Eds), 17, 215-285.

Wilkins, A.L., \& Ouchi, W.G. (1982). Efficient cultures: exploring the relationship between culture and organizational performance. Administrative Sciences Quarterly, 28, 468-81.

Williams, L. J., \& Anderson, S. E. (1991). Job satisfaction and organizational commitment as predictors of organizational citizenship and in-role behavior. Journal of Management, 17, 601617.

Zheng, W., Yang, B., \& McLean, G. N. (2010). Linking organizational culture, structure, strategy, and organizational effectiveness: Mediating role of knowledge management. Journal of Business Research, issue 63, 763-771. 